\title{
MODELLING EU BIOECONOMY CREDENTIALS IN THE ECONOMIC DEVELOPMENT FRAMEWORK: THE ROLE OF INTELLECTUAL CAPITAL
}

\author{
Mirela CRISTEA (D)1, Grațiela Georgiana NOJA (D)2, Nicu MARCU³, \\ Marian SIMINICĂ ${ }^{1}$, Diana-Mihaela T,ÎRCĂ (D) $4^{*}$ \\ ${ }^{1}$ Department of Finance, Banking and Economic Analysis, Center for Banking and Financial Research, \\ Faculty of Economics and Business Administration, University of Craiova, Craiova, Romania \\ ${ }^{2}$ Department of Marketing and International Economic Relations, East European Center for Research in \\ Economics and Business, Faculty of Economics and Business Administration, \\ West University of Timisoara, Timisoara, Romania \\ ${ }^{3}$ The Bucharest University of Economic Studies, Bucharest, Romania \\ ${ }^{4}$ Center of Fundamental and Applied Economic Studies, Faculty of Economics, \\ "Constantin Brancuși” University of Târgu-Jiu, Târgu-Jiu, Romania
}

Received 04 March 2019; accepted 10 May 2020

\begin{abstract}
Given the global importance of bioeconomy for sustainable development and its trendiness in the knowledge driven literature, our research aims to develop a general assessment framework for several shaping factors of bioeconomy fundamentals within the European Union under the decisive impact of the intellectual capital credentials, namely educational attainment, research and development activities and innovation patterns. Considering that there is a high heterogeneity among Member States (MS), selectively regarding the implementation of the intellectual capital in the knowledge economy, but also a differential degree of bioeconomy advances, we have compiled distinct panels on the two groups of EU-28 MS, namely EU-15 (old MS) and EU-13 (new MS). The purpose is to examine the inferences of the intellectual capital in the context of economic development and to shape its role in achieving a sustainable bioeconomy. We have applied several macro-econometric procedures for each considered group, namely: multifactorial macro-econometric models, structural equation modelling (SEM) and Gaussian Graphical Models (GGM), for the period 1995-2016. The results highlight that education, innovation and research, along with main bioeconomy credentials, are at the core of economic development of both EU-13 and EU-15 countries, having distinctive dissimilarities between them, particularly enhanced for the new EU-13 MS.
\end{abstract}

Keywords: bioeconomy, education, innovation, economic development, European Union, econometric procedures.

JEL Classification: C33, I21, O30, O52, Q57.

*Corresponding author. E-mails: diana.pociovalisteanu@gmail.com; diana.mihaela.tirca@gmail.com

Copyright (C) 2020 The Author(s). Published by Vilnius Gediminas Technical University

This is an Open Access article distributed under the terms of the Creative Commons Attribution License (http://creativecommons. org/licenses/by/4.0/), which permits unrestricted use, distribution, and reproduction in any medium, provided the original author and source are credited. 


\section{Introduction}

The economic development of all countries around the world is under the tremendous global confrontation with food support, climate change and resources shortage (Lewandowski et al., 2018; Dragoi et al., 2018). Within this frame of challenges, the need for innovation in the primary sectors becomes foremost, in order to supply more food, exploitation of new resources (bioresources), by biotechnology implementation (Zemlickienè \& Turskis, 2020) and environment protection (Adamowicz, 2017; Bracco et al., 2018). First and foremost, biotechnology "can solve some of the most significant problems in the world, such as providing food for a growing number of people and offering new solutions to the problem of our limited natural resources" (Zemlickienè \& Turskis, 2020, p. 274). Hence, the bioeconomy becomes nowadays one of the most important strategies for modern economic development of all countries (European Commission, 2010, 2012, 2018; OECD, 2009, 2018) and targets for new renewable resources and biomass process ("production, extraction, transformation and consumption") by replacing the limited resources (natural resources). Alongside these targets, the European Union (EU) sets out as main goals included within the bioeconomy's strategies the following (European Commission, 2018, pp. 5-8): the vital support in achievement of the Sustainable Development Goals; new and specific jobs created into the sectors and geographical area enclosed by bioeconomy; climate mitigations, by creating "a carbon neutral future"; industrial reinforcement; the paramount role of urban area, cities becoming "major circular bioeconomy hubs"; and ensuring "healthy ecosystem". A major role in bioeconomy is grounded on the knowledge transfer, known as "knowledge based bioeconomy" (Birner, 2018, p. 19), where the educational attainment, but also research and development support and the innovation (RD\&I) activities (also called "intellectual capital factors") become the primary credentials for the biotechnology implementation, "since biotechnology, as main driver of bioeconomy, needs knowledge on research-development-innovation activities, and highly-skilled people" (Anghel et al., 2019, p. 2716).

Notwithstanding these issues, it is forecasted that, by 2050, the global waste could reach 3.4 billion tonnes and would exceed the population's growth rate, being more emphasised in less developed countries, whereas $90 \%$ of the world's quantity of untreated waste has come up from low-income countries (Kaza et al., 2018). Thereat, specific tailored strategies and programs become essential, particularly in these countries, since "the character of the bioeconomic transformation process is clearly concretized by society and politics" (Pyka \& Prettner, 2018, p. 340).

In this particular setting that grasps the highly significance of the bioeconomy for sustainable economic development, grounded on the intellectual capital support, our special attention is given to the synergy among these dimensions, focusing on dissimilarities existing between old and new EU countries, in a different perspective compared to other studies found in literature (e.g. Bildirici \& Özaksoy, 2018; Nedelea et al., 2018). Therefore, our paper aims to search into bioeconomy and intellectual capital (education, RD\&I activities) implications upon economic development for the EU countries, distinctive for two groups of Member States (MS), respectively the EU-13 new MS (mostly Central and Eastern European countries, CEE) compared with the EU-15 old MS. These connections are analysed for 
the 1995-2016 timespan, by applying the following methodological techniques: (i) several multifactorial macro-econometric models, processed through various techniques (namely, random effects - RE, Two-Stage Least Squares, Instrumental Variables estimators - 2SLS-IV, robust regression - RREG, robust regression bootstrap - Bootstrap RREG, panel-corrected standard errors - PCSE, spatial analysis - Spatial Lag and Spatial Error), in order to assess the direct impact of bioeconomy processes and intellectual capital on economic development; (ii) Structural Equations Modelling (SEM) and (iii) Gaussian Graphical Models (GGM) to evaluate the overall interlinkages among the bioeconomy, intellectual capital and economic development.

The reasons behind the two panels division rely on the need to emphasize the main differences between EU-13 and EU-15, especially as regards the bioeconomy progress and education, RD\&I activities (intellectual capital factors). The bioeconomy approach has been widely debated in literature, especially within the bioeconomy - economic development configuration (e.g. Bracco et al., 2018; Lewandowski et al., 2018; Schutte, 2018; Vargas-Hernandez et al., 2018; Zilberman et al., 2018) or bioeconomy - intellectual capital (Anghel et al., 2019), but the jointly impact of the bioeconomy and intellectual capital upon welfare (economic development) has been less considered, especially for the two specific panels of EU new and old MS. Thus, distinctive from the above investigations, this study captures and fastens a relevant integrative framework of analysis for bioeconomy - intellectual capital economic development relationships, on the two groups of EU MS, the new EU-13 and old EU-15 MS (we have included also the United Kingdom - UK, since Brexit negotiations are in their final stages after the end of January 2020).

The paper is structured as follows: after a brief introduction regarding the novelty and importance of the bioeconomy activities, a synthesized literature review is accomplished. This section is unfold on two main directions: state of the art on bioeconomy approaches, sectors enclosed and the main strategies exerted, particularly within the EU area and the main findings on the bioeconomy - intellectual capital implications upon economic development. Subsequently, we introduce the data processed in the empirical analysis, the methodological endeavour, estimation methods/techniques and the scientific hypotheses. Discussions of the obtained results follow further, which are summarized within the concluding remarks. Extensive information regarding the empirical evidences is enclosed in the Appendix.

\section{Literature review}

\subsection{Bioeconomy concept and the main existing strategies}

Despite of its novelty in economic activities and organizational strategies, the bioeconomy term has a long history, being enhanced through the route of significant scientists' concepts, by "the paradigmatic line Linné-Lyell $\rightarrow$ Davwin $\rightarrow$ Haeckel $\rightarrow$ Antipa $\rightarrow$ Constantinescu $\rightarrow$ Georgescu-Roegen" (Dediu, 2014, p. 59). Georgescu-Roegen (1977, p. 361) brought a significant contribution to the development of the bioeconomy by proposing the entropic approach of the economic process, in order to justify the biological root of the economic activities, and thus "the problem of mankind's existence with a limited store of accessible resources, unevenly located and unequally appropriated". 
Thereby, bioeconomy has received various meanings, mainly consisting of "the sustainable and innovative use of biomass and biological knowledge to provide food, feed, industrial products, bioenergy, and ecological and other services" (Lewandowski et al., 2018, p. 14; Vargas-Hernandez et al., 2018). Bracco et al. (2018, p. 2) assign three important constituents to bioeconomy, namely: "(1) the use of renewable biomass and efficient bioprocesses to achieve sustainable production; (2) the use of enabling and converging technologies, including biotechnology; (3) and integration across applications such as agriculture, health, and industry". In this approach, bieconomy relates to resources (renewable biomass and extraction-transformation-production processes), biotechnology and sectors involved.

Within the EU, the official approach of the bioeconomy comprises all the economic fields "that rely on biological resources (animals, plants, micro-organisms and derived biomass, including organic waste), which includes and interlinks: land and marine ecosystems and the services they provide; all primary production sectors that use and produce biological resources (agriculture, forestry, fisheries and aquaculture); and all economic and industrial sectors that use biological resources and processes to produce food, feed, bio-based products, energy and services" (European Commission, 2018, p. 4).

Ronzon, Santini, and M'Barek (2015) have integrated the bioeconomy sectors in four groups, and their findings show that the EU-13 countries are specialized, mainly, in agriculture (Poland, Romania, Croatia and Slovenia), forestry industry (Estonia and Latvia), or non-specialized sectors (the Czech Republic, Bulgaria, Slovakia and Hungary), while the EU-15 old MS mainly outstand on bio-chemical industries and agro-food industry.

Regarding the bioeconomy determinants, there are various standpoints for measuring its dimensions across regions and countries, through specific indicators, such us: in Argentina bioeconomy is appreciated by bio-based products; in Germany, by the biomass flows offered by the "Systemic Monitoring and Modelling of the Bioeconomy" (SYMOBIO); in the Netherlands, production and consumption of the bio-based raw materials; in South Africa, there are 18 indicators to appreciate the bioeconomy in various sectors grounded on biotechnology innovation activities or knowledge-based economy. Instead, Malaysia has built up a "Bioeconomy Contribution Index" (BCI) to account for bioeconomy impact on the entire economy, as a conjunction of five dimensions: "bioeconomy value added, bio-based exports, bioeconomy investments, bioeconomy employment, and productivity performance" (Bracco et al., 2018, p. 8). Thus, although the bioeconomy concept is granted in the specialists' and organizations' assents since long time ago, the bioeconomy actions were relatively recently included within the regional and national strategies.

Therefore, the Organization for Economic Co-operation and Development (OECD) launched in 2009 the bioeconomy agenda for the perspective to 2030 (OECD, 2009). Within 2030 OECD's bioeconomy agenda, it is foregrounded the interactive role of "biotechnology applications in primary production, R\&D funding, human resources and economic benefits of bioeconomy" (OECD, 2009). In the line of a sustainable bioeconomy, OECD has adopted new policies, which stress out the biomass attention, biotechnology's relevance for bioeconomy sectors, biorefineries and biowaste, bio-production of materials, and the significance of education and training for accomplish biotechnologies competences (OECD, 2018).

At the EU-28 level, the bioeconomy was included within the Europe 2020 strategy and embedded by the national policies tailored to each MS, by advocating the partnerships 
among all MS to attain specific biotechnologies within various bioeconomy sectors ("Innovation Union" initiative). Also, one of the two main groups of indicators included into Europe 2020 relates to "resource efficiency indicators", which monitor the bioeconomy's meeting outcomes (Eurostat, 2019).

The European strategy addressed solely to the bioeconomy and economic growth is "Innovating for Sustainable Growth: A Bioeconomy for Europe", which engendered "the Seventh Framework Programme for Research and Technological Development" (FP7) and the "EU Framework Programme for Research and Innovation" (Horizon, 2020), having a major role in enhancing the education, RD\&I and skills (European Commission, 2012).

This Strategy was advanced in 2017, followed by adopting in 2018 "A sustainable Bioeconomy for Europe: strengthening the connection between economy, society and the environment, Updated Bioeconomy Strategy", which upgraded the specific actions for education, RD\&I, by "proposals for the next Multiannual Financial Framework for 2021-2027 intend to give a significant boost for systemic research and innovation in the areas and sectors covered by the bioeconomy" (European Commission, 2018, p. 7). Also, within the Updated Bioeconomy Strategy, it is stressed out that, by a sustainable bioeconomy, "our economic prosperity and the health of our environment will mutually reinforce one another" (European Commission, 2018, p. 16).

Within the EU, there are supra-national strategies at the level of some MS groups, such us: (i) the "Nordic Bioeconomy Programme", which includes Denmark, Finland and Sweden, and sets out 15 directions in order to enhance bioeconomy sectors (especially the rural development), "to optimise the production and value creation of biomass", the orientation for biotechnology implementation within an "inclusive economic development" (Nordic Council of Ministers, 2018, p. 32; Refsgaard et al., 2018); (ii) the BIOEAST - "Central and Eastern European initiative for knowledge-based agriculture, aquaculture and forestry in the bioeconomy", which encloses 11 CEE countries (the Czech Republic, Bulgaria, Romania, Hungary, Slovakia, Poland, Croatia, Latvia, Lithuania, Estonia and Slovenia), with a particular focus on sustainable bio-economic growth and enhanced cooperation between the EU MS (BIOEAST, 2018).

These strategies reveal a split between East and West within the EU, "with eastern countries serving only as raw material providers for big companies in the west and having limited access to research" (Ronzon \& M'Barek, 2018, p. 7). Enhancing bioeconomy strategies for the EU-13 MS can overwhelm the geographical disparities and heighten unexploited potential, which "will contribute to addressing the EU long-term sustainability challenges in terms of food, energy and jobs security - thereby also establishing the framework for a stronger and deeper cooperation with other EU Member States" (BIOEAST, 2018, p. 3).

\subsection{State of the arts on the bioeconomy - intellectual capital - economic development framework}

The literature on bioeconomy and intellectual capital implications upon economic development comprises an important amount of studies, but which are mainly focused on the relation between each of them. The integrative framework bioeconomy-intellectual capitaleconomic development was less investigated. 
In this regard, Pyka and Prettner (2018) have analysed the manner in which economic growth, development and innovation can lead to knowledge-based bioeconomy. In their study, the authors argued that the negative pressures of environmental pollution, climate change and irrational consumption of resources and energy on economic growth can be mitigated through the knowledge-based bioeconomic production system, thus leading to a sustainable economy.

Cross-examining the existing interdependencies in EU-28 among intellectual capital, circular economy and economic growth, in the context of bioeconomics, Nedelea et al. (2018) stated: on one hand, the favourable influence of the R\&D funding and tax liberty on intellectual property rights embodied in patents, the export of renewable resources, and the rate of municipal waste recycling on economic growth; on the other hand, they have obtained negative effects of innovation in connection to the allocated financing resources and the insufficient use of energy from renewable resources in the industry processes.

Related to bioeconomy - economic development relationship, there are numerous studies which analysed this connection, being proved that bioeconomy represents the prerequisite for a sustainable economic development, "at the crossroads of the sustainable development paradigm" (Vargas-Hernandez et al., 2018, p. 32). Moreover, the sustainable development "is based on an effective economic policy that ensures an optimal interaction between all the economic sectors and the environmental restrictions" (Popescu et al., 2019, p. 59) and can be achieved by "enhancing conservation, recycling, the use of renewable resources, and development of the bioeconomy, which relies on biological processes and feedstock to produce renewable products" (Zilberman et al., 2018, p. 22), through an integrative economic analysis with bioeconomy credentials (Lewandowski et al., 2018).

Further, bioeconomy has enrolled as a "mainstay for achieving a sustainable economy", which must be endorsed by incentive of RD\&I activities and "an efficient international cooperation" (Schutte, 2018, p. 82). The EU specific programmes, such as Horizon 2020, are sustaining the research and innovation (Antoneac \& Dobrota, 2017), bioeconomy being enclosed into the Societal Challenges Pillar.

The education, RD\&I activities (intellectual capital factors) enable economic development by "usage of modern technology as a prerequisite for the technological advances and development", being proved that "the higher amount of patent applications indicates higher technological ability of a country and greater possibilities for significant economic growth and development" (Stevanovic et al., 2018, p. 786). Concerning the contribution of human capital to the total factor productivity growth in the EU countries for the period 1950-2011, Barcenilla, Gimenez, and Lopez-Pueyo (2018, p. 82) concluded that "human capital has a doubly positive effect on economic growth by boosting innovation and by increasing the capacity of countries to absorb foreign technologies". Thus, besides its significant contribution to sustainable development, bioeconomy endorses the modern skill formation of young people and the next generations by education, RD\&I training programs (Anghel et al., 2019; Bildirici \& Ozaksoy, 2018; Bracco et al., 2018). The synergy between bioeconomy and intellectual capital factors revealed that tertiary education, RD\&I outputs are acting as significant constituents in enhancing this interplay, both direct (especially for the new EU-13, as well as for the old EU-15, except the innovation outcomes, which, "contrary to expectation", have induced unfavourable impacts upon bioeconomy coordinates), and overall conjunctions (Anghel et al., 
2019, p. 2716). These results justify the need for bioeconomy-intellectual capital strategies, based on education, learning programs, RD\&I additional efforts, comprehensive knowledge on inter- and transdisciplinary fields, especially for the new EU-13 countries, where public allocations for these actions are reduced (Dybdahl \& Iversen, 2019).

In a nutshell, by reviewing the literature, we have acknowledge the following: the bioeconomy concept encompasses differing meanings, most of them including the renewable energies, along with the biomass production, extraction, transformation and consumption for the biotechnology implementation, attained by education, research and innovation support; there are not common agreed indicators for measuring the bioeconomy dimension within the EU; the role of bioeconomy is enhanced by various measures and directives adopted at the EU level, through the Europe 2020 targets, distinguished across the MS, especially for the two groups, the new EU-13 and old EU-15 countries; there is a consensus related for the high support of bioeconomy in enhancing the economic and sustainable development in Europe; it is underlined the decisive role of RD\&I and particular competences developed in the bioeconomy framework.

\section{Data, methodology, research hypotheses}

Based on the literature underpinnings, since at the EU level lacks a common agreed frame of indicators that can be used to capture the bioeconomy dimensions, our selection of the bioeconomy determinants is grounded on the results of Bracco et al. (2018) and Anghel et al. (2019), which fastened these fundamentals by several processes, namely: renewable biomass and extraction-transformation-production-consumption, grounded of the availability of dataset (Eurostat, 2019). Beside the bioeconomy group of determinants, we have selected two supporting groups of indicators, which measure the economic development (welfare) and intellectual capital dimensions.

Therefore, the data used in our study were framed into three sets of variables, distinctively for the new EU-13 and the old EU-15 MS, drawn up from Eurostat (2019), namely (Table A1, Appendix):

- Economic development: GDP per capita (GDP_cap); "resource productivity, as indicator of resource efficiency by Europe 2020 strategy" (RES_Prod);

- Bioeconomy representative indicators: "primary biomass production and renewable energies (Biorenew_P)"; "gross inland consumption of biomass and renewable wastes (Biomass_Cons)"; "transformation input of biomass and renewable wastes (Biomass_ TI)"; "biomass domestic extraction (Biomass_EXT)"; "biomass exports (Biomass_X)"; and "biomass imports (Biomass_M)";

- Intellectual capital indicators, namely: "tertiary education level 30-34 age group (EDU_Tert)"; "population with secondary, upper, post-secondary and tertiary education (levels 3-8) (EDU)"; "Research and Development $(R \& D)$ expenditures $\left(R D_{-}\right.$ Exp)"; "patents on recycling and secondary raw materials (Patents_recy)".

The timespan period is 1995-2016. For the EU-13 MS panel, we have enclosed a total number of 286 observations, and for the EU-15 MS panel there are 330 observations (Table A2, Appendix). 
The bioeconomy representative indicators in 2016 (Figure 1) highlight significant outcomes for the countries comprised in the EU-15 panel, namely France, Germany, Italy and the UK (all bioeconomy considered indicators, except Biomass_X), Finland, Sweden and Denmark (for Biorenew_P, Biomass_TI, and Biomass_Cons), Germany, Spain, Austria, the Netherlands (for Biomass_X), and Spain (for Biomass_EXT). Instead, at the level of EU-13 panel, there are only four countries with relevant bioeconomy allocation, namely Poland (for Biorenew_P, Biomass_Cons and Biomass_X), Latvia and Estonia (for Biomass_X), and Romania (for Biomas_EXT).

The intellectual capital indicators for 2016 (Figure 2) in the EU-15 panel reveal that the most substantial EDU_Tert attainments (Figure 2a) were in Sweden, Denmark, Ireland and the UK, while in the case of EU-13 MS, only two countries, namely Cyprus and Lithuania, have accounted high levels of tertiary education. As regards $R D \_\exp$ (Figure 2b), the highest allotment was registered only in the EU-15 developed countries, namely Austria, Belgium, France, Germany, and the Nordic Countries (Finland, Sweden and Denmark). The significant Patents_recy (Figure 2c) was persistent in a number of MS from the EU-15 (namely Belgium, France, Spain, Germany, Italy and Finland), as well as Poland, from the EU-13 panel.

The research methodology comprises several econometric procedures, distinctive for each panel, EU-13 and EU-15, namely: (1) multifactorial macro-econometric models, processed through various estimation procedures, namely: random effects - RE; Two-Stage Least Squares, Instrumental Variables estimators - 2SLS-IV; robust regression, RREG; robust regression bootstrap, Bootstrap RREG; panel-corrected standard errors, PCSE; spatial analysis, Spatial Lag and Spatial Error; (2) Structural Equation Modelling (SEM), configured to assess the direct, indirect and total interlinkages between the bioeconomy outcomes, intellectual capital factors and GDP per capita; and (3) Gaussian graphical models (GGM), to account for the interdependencies between the considered variables.

Firstly, in order to withdraw the related differences between countries data, we have considered the standardisation technique, consisting in developing several composite indicators (OECD, 2008). Thus, we target an accurate comprehensive assessment of the interdependences between the economic activity, bioeconomy outcomes and intellectual capital factors, in a different approach compared to other studies in the literature on the same topic (e.g. Bildirici \& Özaksoy, 2018; Nedelea et al., 2018; Cîrstea et al., 2019).

Further, the multifactorial macro-econometric model is,represented by equation (1).

$$
G D P \_c a p_{i t}=\alpha_{0}+\alpha_{1} E D U_{-} \text {Tert }_{i t}+\alpha_{2} \text { Patents_recy }_{i t}+\alpha_{3} R E S_{-} \text {prod }_{i t}+\alpha_{4} \text { Biomass_TI }_{i t}+
$$
$\alpha_{5}$ Biomass_EXT $T_{i t}+\alpha_{6}$ Biomass_ $M_{i t}+\alpha_{7}$ Biomass_ $X_{i t}+\alpha_{8}$ Biomass_ $P_{i t}+\varepsilon_{i t}$.

Relevant choices to achieve unbiased estimators sidestepping the endogeneity issue are by grasping numerous models and procedures (McKenzie \& Sasin, 2007). On these lines and conforming with previous studies with similar research methodology (Bildirici \& Özaksoy, 2018; Anghel et al., 2019), yet different than other approaches (Alsaleh et al., 2017; Kung, 2018; Cîrstea et al., 2019), to ensure robustness and accuracy of the estimations, to avoid spurious regressions and overcome the limitations of traditional methods, we have went beyond the classical widely used Ordinary Least Squares (OLS) method, to process the general model based on seven techniques. Hence, we have applied: (i) random effects (RE) that 

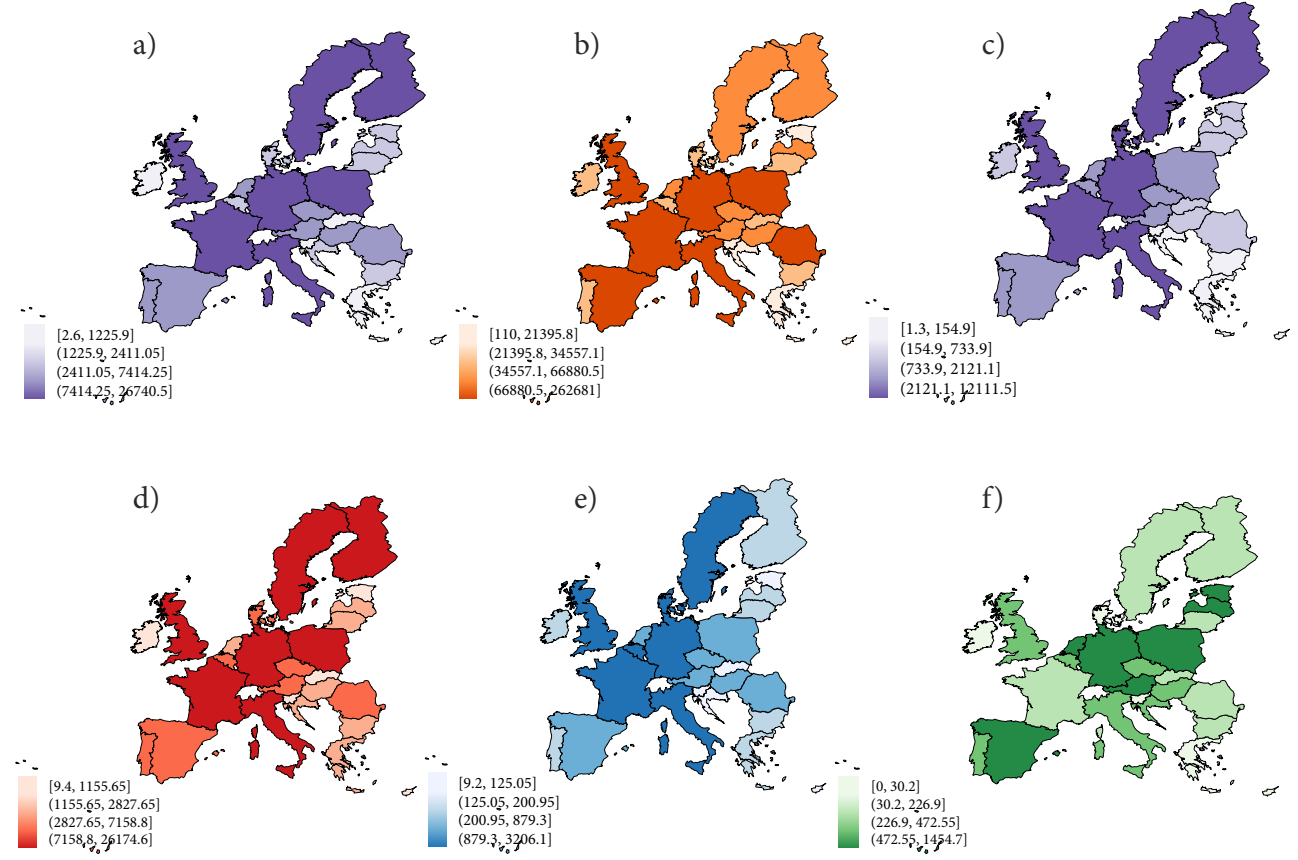

Figure 1. The main indicators of the bioeconomy in 2016 in the EU-28: a - Biorenew_P; $\mathrm{b}$ - Biomass_EXT; c - Biomass_TI; d - Biomass_Cons; e - Biomass_M ; $\mathrm{f}-$ Biomass_X (source: own contribution in Stata)

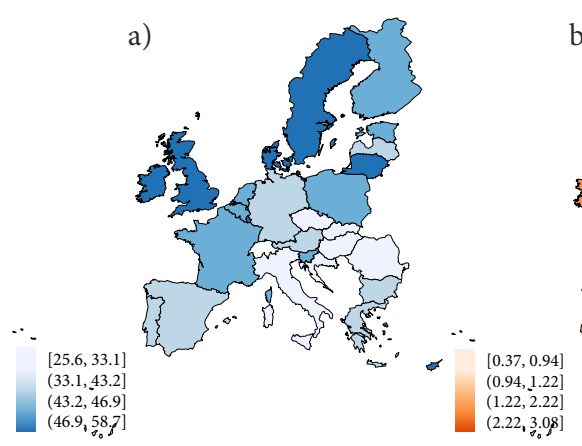

b)

Figure 2. Intellectual capital in EU-28 in 2016: a - EDU_Tert; b - RD_Exp; c - Patents_recy (source: own contribution in Stata)

capture individual heterogeneity, and captures the impact of each country considered in the panel data analysis as an arbitrary extraction uncorrelated with the regressors (Baum, 2006); (ii) Two-Stage Least Squares, Instrumental Variables estimators (2SLS-IV), as an extension of the OLS method and an alternative technique in SEM modelling, to perform endogeneity control and have a double check of the empirical results (Wooldridge, 2013); (iii) robust regression (RREG) and (iv) robust regression bootstrap (Bootstrap RREG), which weights each observation differently, rather than treating them equally as in the case of an OLS 
regression, thus avoiding the results being driven by larger economies as panel sub-units (Baum, 2006); (v) panel-corrected standard errors (PCSE) for panel corrections validating the cross-sectional (and temporal) dependence, thus allowing for robust estimates (Wooldridge, 2013); and spatial analysis, namely (vi) Spatial Lag and (vii) Spatial Error models, designed to apprehend the spatial inferences (Sanders, 2007), by capturing the spatial spillover impacts of the intellectual capital and bioeconomy determinants on GDP per capita.

Forwards, we have configured Structural Equation Modelling (SEM), a developed multivariate analysis procedure (Wooldridge, 2013). The general configuration of the SEM model is presented in the equation system 2 (Anghel et al., 2019, p. 2709).

$$
\left\{\begin{array}{l}
b_{11} y_{1 t}+\ldots .+b_{1 m} y_{m t}+c_{11} x_{1 t}+\ldots+c_{1 n} x_{n t}=\varepsilon_{1 t} \\
b_{21} y_{1 t}+\ldots .+b_{2 m} y_{m t}+c_{21} x_{1 t}+\ldots+c_{2 n} x_{n t}=\varepsilon_{2 t} \\
\ldots \ldots \ldots . . . \\
b_{m 1} y_{1 t}+\ldots .+b_{m m} y_{m t}+c_{m 1} x_{1 t}+\ldots+c_{m n} x_{n t}=\varepsilon_{m t}
\end{array},\right.
$$

where: $t$ - the number of periods of time observed; $b_{i j}$ - parameters of endogenous variables $y_{i j} ; c_{i j}$ - parameters of exogenous variables $x_{i j} ; i=1, \ldots, m ; j=1, \ldots, n$.

Within the SEM framework, measurement error variables that correspond to the measurement error portions of observed variables (specific for data in social sciences) are explicitly included thus controlling for measurement error and providing accurate and reliable conclusions about the relationships between variables (constructs), by allowing to test the model and its compatibility with the data in its entirety.

Ultimately, to encompass the interdependencies between the explanatory dimensions of bioeconomy, intellectual capital and economic development, we have also deemed regressions lead by Gaussian Graphical Models (GGMs), thus catching the advantages given by covariance structures (Dobra et al., 2008). The GGM "shows which variables predict one-another, allows for sparse modelling of covariance structures, and may highlight potential causal relationships between observed variables" (Epskamp et al., 2018, p. 453). Moreover, Epskamp et al. (2018, p. 474) further entail the decisive importance of GGMs and conclude that "estimating GGMs offers an attractive alternative in that these models are uniquely identified, well parameterized, closely related to causal models and also offer exploratory insight on predictive effects between observed variables".

According with our methodological endeavour, and relying on a critical review of the literature, we put forward to test two research hypotheses $(H)$ :

H1. There are important inferences of bioeconomy outcomes and intellectual capital coordinates (educational attainment and RD\&I) on economic development;

H2. There are tight overall linkages between the bioeconomy credentials significantly shaped by the intellectual capital factors and economic development. 


\section{Results and discussions}

\subsection{Results of multifactorial macro-econometric models}

Sequence to examine how the intellectual capital and bioeconomy processes jointly influence the welfare measured through the GDP per capita, we have developed a multifactorial macroeconometric model (Table 1). This general model was processed through seven estimation procedures presented into previous sections, namely: model 1 - RE, model 2 - 2SLS-IV, model 3 - RREG, model 4 - Bootstrap RREG, model 5 - PCSE, model 6 - Spatial Lag, and model 7 - Spatial Error.

Table 1. Results of macro-econometric models developed to identify the effects of bioeconomy and intellectual capital upon GDP per Capita, EU-13 and EU-15, 1995-2016 (source: authors' research)

\begin{tabular}{|c|c|c|c|c|c|c|c|}
\hline EU-13 & (1) & (2) & (3) & (4) & (5) & (6) & (7) \\
\hline Variables & $\mathrm{RE}$ & 2SLS-IV & RREG & Bootstrap RREG & PCSE & Spatial Lag & Spatial Error \\
\hline EDU_Tert & $\begin{array}{l}0.0751^{* * *} \\
(0.00993)\end{array}$ & $\begin{array}{c}-0.00337 \\
(0.0645)\end{array}$ & $\begin{array}{l}0.0665^{* * *} \\
(0.0115)\end{array}$ & $\begin{array}{c}0.0665^{*} \\
(0.0266)\end{array}$ & $\begin{array}{l}0.112^{* * *} \\
(0.0102)\end{array}$ & $\begin{array}{l}0.0661^{* * *} \\
(0.0187)\end{array}$ & $\begin{array}{l}0.0763^{* *} \\
(0.0284)\end{array}$ \\
\hline Patents_recy & $\begin{array}{l}-0.130^{* *} \\
(0.0413)\end{array}$ & $\begin{array}{l}-0.574 \\
(0.341)\end{array}$ & $\begin{array}{l}-0.0599 \\
(0.0817)\end{array}$ & $\begin{array}{l}-0.0599 \\
(0.0749)\end{array}$ & $\begin{array}{l}-0.0704 \\
(0.0586)\end{array}$ & $\begin{array}{c}-0.101 \\
(0.0607)\end{array}$ & $\begin{array}{l}-0.0865 \\
(0.0567)\end{array}$ \\
\hline RES_Prod & $\begin{array}{c}0.0547^{*} \\
(0.0260)\end{array}$ & $\begin{array}{l}-0.171 \\
(0.181)\end{array}$ & $\begin{array}{l}0.387^{* * *} \\
(0.0268)\end{array}$ & $\begin{array}{l}0.387^{* * *} \\
(0.0276)\end{array}$ & $\begin{array}{l}0.349^{* * *} \\
(0.0291)\end{array}$ & $\begin{array}{l}0.366^{* * *} \\
(0.0290)\end{array}$ & $\begin{array}{l}0.367^{* * *} \\
(0.0276)\end{array}$ \\
\hline Biomass_TI & $\begin{array}{c}0.212^{* *} \\
(0.0645)\end{array}$ & $\begin{array}{l}-2.995 \\
(2.148)\end{array}$ & $\begin{array}{c}0.197 \\
(0.117)\end{array}$ & $\begin{array}{c}0.197 \\
(0.105)\end{array}$ & $\begin{array}{c}0.141 \\
(0.0736)\end{array}$ & $\begin{array}{c}0.168^{*} \\
(0.0757)\end{array}$ & $\begin{array}{c}0.157^{*} \\
(0.0744)\end{array}$ \\
\hline Biomass_EXT & $\begin{array}{c}0.0741 \\
(0.0400)\end{array}$ & $\begin{array}{l}-1.025 \\
(0.763)\end{array}$ & $\begin{array}{l}-0.0240 \\
(0.0299)\end{array}$ & $\begin{array}{l}-0.0240 \\
(0.0208)\end{array}$ & $\begin{array}{l}-0.0356^{*} \\
(0.0177)\end{array}$ & $\begin{array}{l}-0.0199 \\
(0.0206)\end{array}$ & $\begin{array}{l}-0.0290 \\
(0.0207)\end{array}$ \\
\hline Biomass_M & $\begin{array}{l}-0.183^{* * *} \\
(0.0502)\end{array}$ & $\begin{array}{l}-0.293 \\
(0.210)\end{array}$ & $\begin{array}{l}-0.0942 \\
(0.0914)\end{array}$ & $\begin{array}{l}-0.0942 \\
(0.0628) \\
\end{array}$ & $\begin{array}{l}-0.0672 \\
(0.0440) \\
\end{array}$ & $\begin{array}{l}-0.0711 \\
(0.0459) \\
\end{array}$ & $\begin{array}{l}-0.0485 \\
(0.0455) \\
\end{array}$ \\
\hline Biomass_X & $\begin{array}{l}0.0894^{* * *} \\
(0.0167)\end{array}$ & $\begin{array}{l}-0.383 \\
(0.324)\end{array}$ & $\begin{array}{c}0.0117 \\
(0.0232)\end{array}$ & $\begin{array}{c}0.0117 \\
(0.0241)\end{array}$ & $\begin{array}{l}-0.0297 \\
(0.0185)\end{array}$ & $\begin{array}{l}-0.0206 \\
(0.0170)\end{array}$ & $\begin{array}{l}-0.0234 \\
(0.0169)\end{array}$ \\
\hline Biorenew_P & & $\begin{array}{c}5.871 \\
(3.906)\end{array}$ & & & & & \\
\hline _cons & $\begin{array}{l}2.040^{* * *} \\
(0.0682)\end{array}$ & & $\begin{array}{l}2.258^{* * *} \\
(0.0327)\end{array}$ & $\begin{array}{l}2.258^{* * \star} \\
(0.0259)\end{array}$ & $\begin{array}{l}2.238^{* * *} \\
(0.0307)\end{array}$ & $\begin{array}{l}1.199^{* * *} \\
(0.244)\end{array}$ & $\begin{array}{l}2.248^{* * *} \\
(0.0444)\end{array}$ \\
\hline$N$ & 286 & 286 & 286 & 286 & 286 & 286 & 286 \\
\hline$R^{2}$ & & 0.281 & 0.547 & 0.547 & 0.508 & & \\
\hline$E U-15$ & (1) & (2) & (3) & (4) & (5) & (6) & (7) \\
\hline Variables & $\mathrm{RE}$ & 2SLS-IV & RREG & $\begin{array}{l}\text { Bootstrap } \\
\text { RREG }\end{array}$ & PCSE & Spatial Lag & Spatial Error \\
\hline EDU_Tert & $\begin{array}{l}0.224^{* * *} \\
(0.0188)\end{array}$ & $\begin{array}{l}0.268^{*} \\
(0.127)\end{array}$ & $\begin{array}{l}0.177^{* * *} \\
(0.0263)\end{array}$ & $\begin{array}{l}0.177^{* * *} \\
(0.0363)\end{array}$ & $\begin{array}{l}0.0987^{* * *} \\
(0.0192)\end{array}$ & $\begin{array}{c}0.0264 \\
(0.0361)\end{array}$ & $\begin{array}{c}0.0907 \\
(0.0544)\end{array}$ \\
\hline Patents_recy & $\begin{array}{c}-0.0477^{* *} \\
(0.0158)\end{array}$ & $\begin{array}{c}-0.00356 \\
(0.133)\end{array}$ & $\begin{array}{c}0.0346 \\
(0.0237) \\
\end{array}$ & $\begin{array}{c}0.0346 \\
(0.0281) \\
\end{array}$ & $\begin{array}{l}0.0826^{* *} \\
(0.0254)\end{array}$ & $\begin{array}{l}0.0705^{* * *} \\
(0.0185)\end{array}$ & $\begin{array}{l}0.0620^{* *} \\
(0.0197)\end{array}$ \\
\hline RES_Prod & $\begin{array}{l}0.185^{* * *} \\
(0.0309)\end{array}$ & $\begin{array}{c}0.142 \\
(0.127)\end{array}$ & $\begin{array}{l}0.188^{* * *} \\
(0.0294)\end{array}$ & $\begin{array}{c}0.188 \\
(0.174)\end{array}$ & $\begin{array}{l}0.599^{* * *} \\
(0.0343)\end{array}$ & $\begin{array}{l}0.556^{* * *} \\
(0.0559)\end{array}$ & $\begin{array}{l}0.578^{* * *} \\
(0.0588)\end{array}$ \\
\hline Biomass_TI & $\begin{array}{l}0.0530^{* *} \\
(0.0202)\end{array}$ & $\begin{array}{l}-0.381 \\
(1.326)\end{array}$ & $\begin{array}{l}0.143^{* * *} \\
(0.0296)\end{array}$ & $\begin{array}{l}0.143^{* * *} \\
(0.0260)\end{array}$ & $\begin{array}{l}0.195^{* * *} \\
(0.0269)\end{array}$ & $\begin{array}{l}0.202^{* * *} \\
(0.0259)\end{array}$ & $\begin{array}{l}0.206^{* * *} \\
(0.0307)\end{array}$ \\
\hline
\end{tabular}


End of Table 1

\begin{tabular}{|l|c|c|c|c|c|c|c|}
\hline \multicolumn{1}{|c|}{ EU-13 } & $(1)$ & $(2)$ & $(3)$ & $(4)$ & $(5)$ & $(6)$ & $(7)$ \\
\hline \multirow{2}{*}{ Biomass_EXT } & $0.0923^{*}$ & $0.111^{*}$ & $-0.120^{* * *}$ & -0.120 & $-0.268^{* * *}$ & $-0.245^{* * *}$ & $-0.243^{* * *}$ \\
& $(0.0393)$ & $(0.0497)$ & $(0.0246)$ & $(0.0667)$ & $(0.0324)$ & $(0.0337)$ & $(0.0328)$ \\
\hline Biomass_M & $-0.0900^{* * *}$ & -0.0651 & $-0.0880^{* * *}$ & -0.0880 & $-0.270^{* * *}$ & $-0.257^{* * *}$ & $-0.265^{* * *}$ \\
& $(0.0154)$ & $(0.0738)$ & $(0.0242)$ & $(0.0800)$ & $(0.0235)$ & $(0.0319)$ & $(0.0341)$ \\
\hline Biomass_X & $-0.0391^{* *}$ & -0.0869 & $-0.0562^{*}$ & -0.0562 & $-0.152^{* * *}$ & $-0.145^{* * *}$ & $-0.155^{* * *}$ \\
& $(0.0140)$ & $(0.144)$ & $(0.0249)$ & $(0.0460)$ & $(0.0335)$ & $(0.0285)$ & $(0.0315)$ \\
\hline Biorenew_P & & 0.603 & & & & & \\
\hline \multirow{2}{*}{ cons } & $(1.839)$ & & & & & \\
\hline$N$ & $(0.155)$ & & $(0.0251)$ & $(0.0378)$ & $(0.0276)$ & $(0.288)$ & $(0.408)$ \\
\hline$R^{2}$ & 330 & 330 & 330 & 330 & 330 & 330 & 330 \\
\hline
\end{tabular}

Note: Standard errors are shown into the brackets, ${ }^{*} \mathrm{p}<0.05,{ }^{* *} \mathrm{p}<0.01,{ }^{* * *} \mathrm{p}<0.001$.

All of these methods and estimation techniques have allowed us to confirm the model specification, and to ensure robust results that are valid and accurate (Appendix, Table A3 for unit-root tests). Thus, we entail new empirical evidence that allows us to attest that tertiary education (EDU_Tert) represents a fundamental factor of economic growth that leads to welfare and significant increases in GDP per capita levels both for EU-13 MS (positive estimated coefficients throughout various econometric techniques applied, e.g. 0.112 for PCSE, and 0.0665 for RREG, statistically significant), and EU-15 MS (positive coefficients obtained for all estimation procedures, e.g. 0.0987 for PCSE, and 0.177 for RREG). These findings are similar with those achieved by Antoneac and Dobrota (2017), and Tondl and Vuksic (2003). The coefficients associated with EDU_Tert for the spatial models (lag - model 6 and error model 7) are also positive and statistically significant in both samples (EU-13 and EU-15), thus entailing that the tertiary educational performance of the neighbouring locations are also important in shaping the economic development of EU countries, in conjunction with bioeconomy credentials.

On the other hand, when we have considered the EU-13 countries, we noted that low achievements for "patents registration and innovation on recycling and secondary raw materials (Patents_recy)" induce negative effects upon the GDP per capita (negative estimated coefficients for all econometric techniques, even though with a lower degree of statistical significance, e.g. -0.0704 PCSE and -0.0599 RREG). The EU-15 MS, however, acknowledge an innovation activity in this field which positively reverberates on the economic welfare (positive estimated coefficients for almost all procedures, namely 0.0826 PCSE, and 0.0346 RREG, with a higher degree of statistical significance). The results for EU-13 are in line with Dobrzanski (2018), Nedelea et al. (2018), and Stevanovic et al. (2018), which revealed that, for the CEE countries, a significant upturn in innovation activities captured by the increase in the number of patent applications had adverse (reduction) effects on GDP per capita levels, possibly due to the inappropriate application of the registered patents or insufficient benefits resulting from these actions. Moreover, one of the main bioeconomy credential, „transformation input of biomass and renewable wastes (Biomass_TI)", leads to significant increases 
in GDP per capita, generating an overall positive impact on economic development, both for EU-13 (positive coefficients of 0.141 PCSE and 0.197 RREG), but especially in the case of EU-15 (positive and highly statistically significant coefficients of 0.195 PCSE and 0.143 RREG). This result completes the main findings of several researchers (e.g. Luhova, 2015; Zilberman et al., 2018), which revealed that the bioeconomy provides the premises for a high potential of economic and sustainable development in the EU. However, if we consider the production of primary biomass and renewable energies (Biorenew_P) introduced only in the second model (2SLS-IV) as instrumental variable, we have noticed that it has a positive impact both on the EU-13 (estimated coefficient of 5.871), and EU-15 (estimated coefficient of 0.603 ), even though the estimated coefficients have a lower degree of statistical significance. These results are in line with those obtained by Kung (2018) and Alsaleh et al. (2017), which analysed the bioenergy development in case of Taiwan, respectively in EU-28, and opposite to Cîrstea et al. (2019, p. 82), which argued that "bioenergy negatively correlates with the economic efficiency of a state".

Resource productivity (RES_Prod) also generates positive consequences on GDP per capita levels, its increase leading to important improvements in the economic welfare both for EU-13 and EU-15 (positive estimated coefficients that are highly significant from a statistical point of view). Nevertheless, the biomass extraction (Biomass_EXT), biomass exports and imports (Biomass_X, respectively Biomass_M), tend to induce negative effects on EU-15 MS by reducing the GDP per capita level, while in the case of EU-13 these results are inconclusive, but also primarily negative.

Thus, based on multifactorial macro-econometric models, the $1^{\text {st }}$ hypothesis, $H_{1}$ : There are important inferences of bioeconomy outcomes and intellectual capital coordinates (educational attainment and $R D \& I$ ) on economic development, is partially fulfilled. The results reveal the fundamental importance of EU specific policies/strategies encompassing intellectual capital factors oriented to the field of bioeconomy, in order to further enhance tertiary education, both for the EU-13 and EU-15 countries, and better utilization of the registered patents within developing countries, combined with diminished expenses of patent protection. According to our results, special attention for both groups of EU countries needs to be granted to biomass domestic extraction, as well as to biomass exports and imports.

\subsection{Results of the SEM models}

Based on previous results obtained after processing several macro-econometric models, we have expanded our empirical research by designing a new comprehensive framework of analysis that binds both the modellers of the bioeconomy fundamentals in conjunction with the intellectual capital factors, and their consequences for long-term development, and economic welfare (reflected by the GDP per capita). The general SEM model and the results obtained for each of the sub-samples of EU countries considered, EU-13 and EU-15, are graphically represented in Figure 3.

Both SEM models processed through the Maximum Likelihood estimation method (MLE) were subject to numerous validation tests as entailed by Wooldridge (2013). The outputs of these specific tests (presented in the Appendix, Tables A4-A6) highlight the robustness and accuracy of our estimations. SEM results synthesized in Figure 3(a) reveal that, in the case of the new EU-13 MS, the intellectual capital, measured here by tertiary 
education (EDU_Tert), leads to decreasing of the production of biomass and renewable energies (Biorenew_P) (a negative coefficient, -0.016), leading to downwards also in biomass extraction (Biomass_EXT) (the estimated coefficient -0.056 and statistically significant). These results are consistent with those obtained by Anghel et al. (2019). However, positive effects upon bioeconomy outcomes are induced by an upward in the innovation activities and the compelling support of R\&D processes (Patents_recy) (positive estimated coefficient and significant from a statistical point of view at the $0.1 \%$ level). This result is adverse to those registered by Nedelea et al. (2018), in case of all EU MS. Beneficial bioeconomy consequences of the "intellectual capital (EDU_Tert and Patents_recy)" are induced in terms of "transformation input of biomass and renewable wastes (Biomass_TI)" (similar to Anghel et al., 2019), with positive cascade effects upon GDP per capita (the estimated coefficient is $0.59, \mathrm{p}<0.001)$. Educational attainment for non-tertiary education $(E D U)$ induces positive impacts upon bioeconomy dimensions, more significant for biomass exports (Biomass_X) (the estimated coefficient is 0.21 ), as well as $\mathrm{R} \& \mathrm{D}$ expenditures ( $\left.R D \_E x p\right)$ (except for „consumption of biomass and renewable wastes - Biomass_Cons"). Positive impacts of the intellectual capital (EDU and $\left.R D \_E x p\right)$ are registered upon the biomass imports (Biomass_M) and biomass consumption (Biomass_Cons), with favourable cascade effects upon GDP per capita (the estimated coefficient is 0.2), as entailed also by the European Commission (2018).
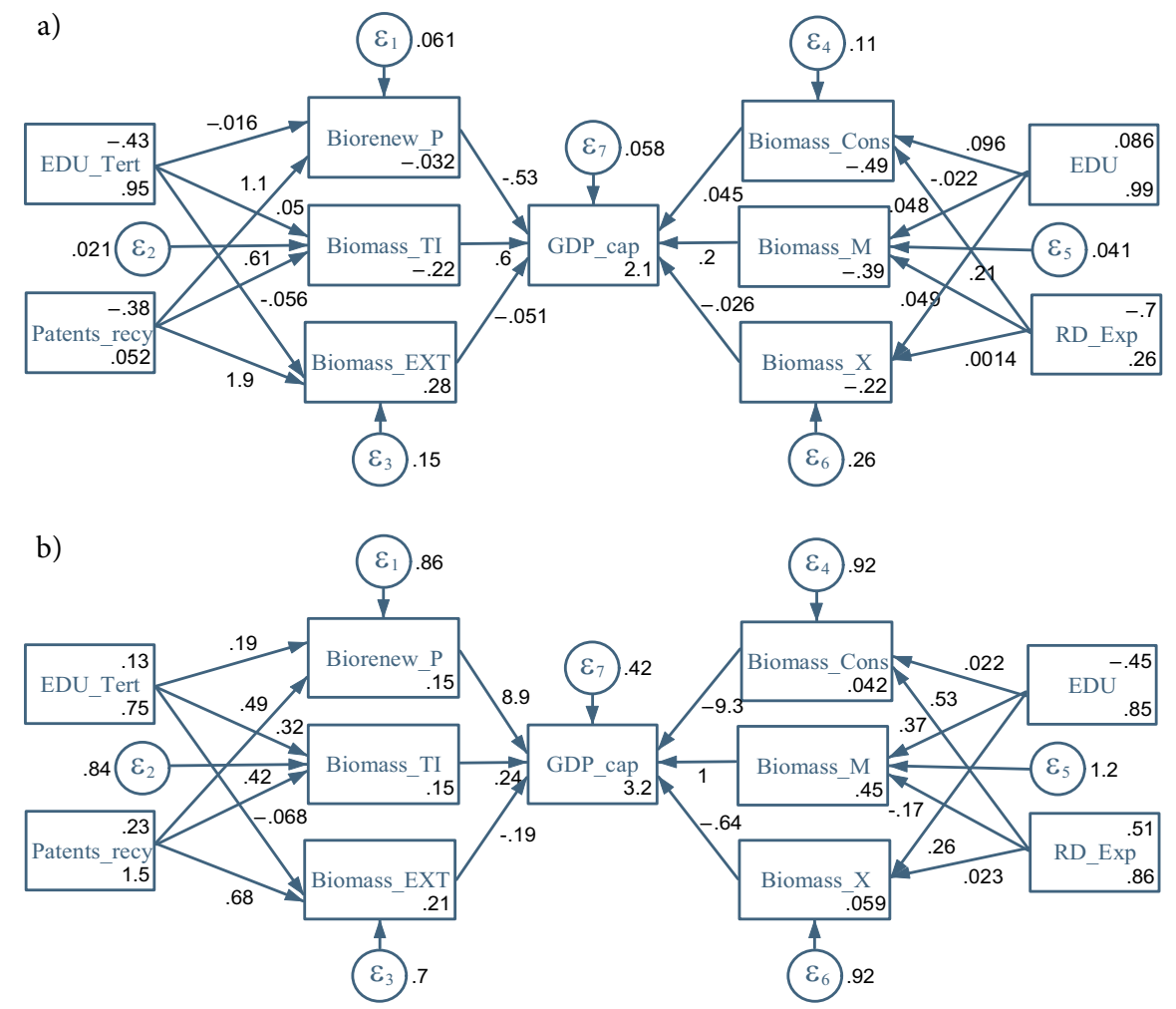

Figure 3. SEM models configured to assess the linkages between bioeconomy, intellectual capital and economic development, 1995-2016: a - EU-13; b - EU-15 (source: own research) 
However, there are other bioeconomy coordinates with negative effects on GDP per capita in the EU-13, like "primary biomass production and renewable energies (Biorenew_P)", "biomass extraction (Biomass_EXT)" and "biomass exports (Biomass_X)". Thus, compared with direct implications of bieconomy upon economic development of the EU-13, the previous results obtained through multifactorial macro-econometric models are similar, except for production of biomass and renewable energies (Biorenew_P), which have generated an increase in GDP per capita.

On the other hand, for the old EU-15 MS (Figure 3b), the intellectual capital, measured by tertiary education (EDU_Tert), contributes to the growth of "primary biomass production (Biorenew_P)" (the estimated coefficient is $0.19, \mathrm{p}<0.001$ ). Positive effects are also generated on the degree of transformation of biomass and renewable wastes (Biomass_TI) (the coefficient is $0.32, \mathrm{p}<0.001$ ). Furthermore, an upward in "the number of patent applications (Patent_recy)" has favorable outcomes on all considered biomass variables, especially for Biomass_Ext (coefficient is 0.68). These findings are in line with those obtained by Anghel et al. (2019). Similar with the results for the EU-13, non-tertiary education (EDU) and R\&D expenditures $\left(R D \_E x p\right)$ induce positive impacts upon bioeconomy dimensions (except for biomass imports - Biomass_M in the case of $R D \_E x p$ ). In the standpoint of the indirect effects induced by the bioeconomy and intellectual capital factors on GDP per capita, a significant favorable effect is induced by "the production of biomass and renewable energies (Biorenew_P)" (coefficient is 8.9), the biomass transformation process (Biomass_TI) (coefficient is 0.24 ), and the biomass imports (Biomass_M) (coefficient is 1.03), while the other bioeconomy considered coordinates (Biomass_EXT, Biomass_Cons and Biomass_X) would generate adverse effects (negative estimated coefficients). Compared with previous results obtained by multifactorial macro-econometric models for direct effects of bieconomy upon GDP per capita, the SEM results are similar, except for biomass imports (Biomass_M), which induces a direct beneficial impact upon GDP per capita.

As a summary, for the new EU-13 MS, there are beneficial consequences of the intellectual capital factors (EDU_Tert, Patents_recy, EDU and RD_Exp), jointly with the "transformation input of biomass and renewable wastes (Biomass_TI)", the "biomass imports (Biomass_M)" and the "consumption of biomass and renewable wastes (Biomass_Cons)" on the economic development (GDP_cap). Furthermore, in case of the EU-15, the intellectual capital has a decisive role in advancing the economic growth and welfare in this integrative framework, by positively influencing "the primary biomass production and renewable energies (Biorenew_P)", "biomass transformation and renewable wastes (Biomass_TI)", and "biomass imports (Biomass_M)". Thus, the conjunction of intellectual capital - bioeconomy can convey a large added value for production, transformation and imports of biomass and renewable energies, sharpen the competition between conventional jobs and these new kinds of bioeconomy jobs, and encourage the application of "circularity principles", which will enhance the sustainable economic development (Gomez San Juan, et al., 2019, p. XIX). Besides, the EU, and more specific Italy, is mentioned in a best practice setting in terms of using carbon as biomass, "to produce energy and high-value compounds" (Gomez San Juan et al., 2019, p. 41). 
Thus, based on SEM results, the $2^{\text {nd }}$ hypothesis, $\mathrm{H}_{2}$ : There are tight overall linkages between the bioeconomy credentials significantly shaped by the intellectual capital factors and economic development, is partially fulfilled. It is therefore entailed the keen need to design targeted policies/strategies for each specific group of EU countries, in order to support the synergy between intellectual capital-bioeconomy-economic development, as keystone for sustainable development (also outlined by Vargas-Hernandez et al., 2018).

\subsection{Results of the Gaussian Graphical Models}

By acknowledging the importance of assessing and graphically representing all the interlinkages between bioeconomy, intellectual capital and economic development, we've further proceeded to design several Gaussian Graphical Models (GGMs) as counterparts of our SEM models, since, compared to SEM, "a key advantage of the GGM approach is that model uncertainty can be easily incorporated into the framework" (Dobra et al., 2008, p. 3). GGMs ensure a deeper and comprehensive understanding of the intensity of connections across selected measures/proxies used throughout the entire research endeavour to capture the essential role of bioeconomy credentials and intellectual capital for economic growth and sustainable development. As previous studies outline "this new approach based on graphical models holds the advantage of relaxing the strict conditional independence constraints denoted by the linear regression models and thus distinctly captures the complex dependency patterns" (Marcu et al., 2018, p. 13; Dobra et al., 2008). Also, "the GGM shows which variables predict one-another, allows for sparse modelling of covariance structures, and may highlight potential causal relationships between observed variables" (Epskamp et al., 2018, p. 453).

There are two regularized GGM models deployed for each sub-panel of EU-13 (Figure 4) and EU-15 (Figure 5) countries, during 1995-2016, processed through $a$ ) joint multivariate Least Absolute Shrinkage and Selection Operator (LASSO) estimation with Extended Bayesian Information Criterion (EBIC) model selection and $b$ ) Partial correlation (undirected network).

The two GGMs accounted for the EU-13 panel (Figure 4) reinforce and emphasize the strong two-fold relationships between intellectual capital, respectively bioeconomy processes and economic growth (captured through GDP_cap), as previously entailed by the European Commission (2018) and Nedelea et al. (2018). Basically, there are two patterns revealed for the new EU-13 MS in terms of sustainable economic development, one where at the core of GDP per capita levels lie the intellectual capital variables (EDU, EDU_Tert and Patents_recy), and the other shaped by several important bioeconomy credentials (particularly Biomass_Ext, Biomass_Cons, Biorenew_P). Thus, undoubtedly, the essential role of education and innovation, as well as of bioeconomy undertakings, is restated for the EU-13 new MS, as main drivers of welfare and economic advances. These sheer implications of the intellectual capital and bioeconomy features on economic growth must be considered by the policy makers across the EU to redesign new accurate and comprehensive strategies that place these two fundamentals at the core of sustainable economic development. 


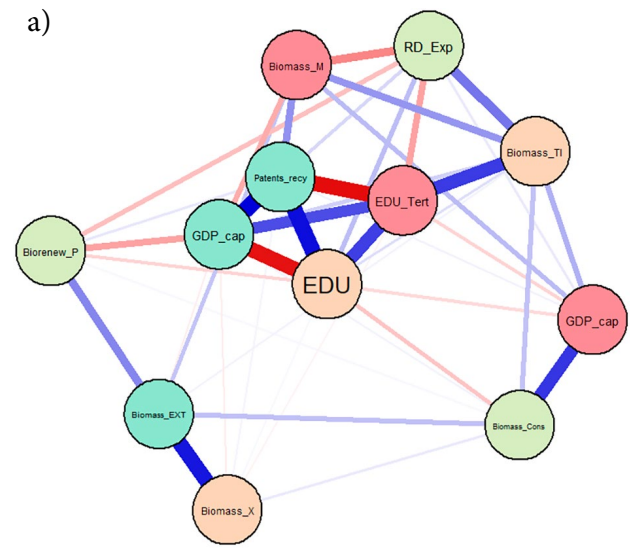

GDP_cap: GDP per capita; RD_Exp: R\&D expenditures; EDU: Educated population; EDU_Tert: Tertiary education; Patents_recy: Patents on recycling and secondary; Biomass_Cons: Biomass consumption;

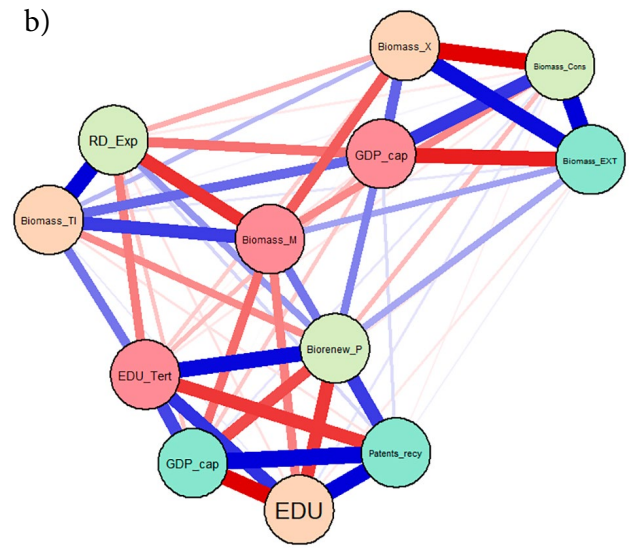

Biomass_TI: Biomass transformation input; Biomass_M: Biomass imports; Biomass_EXT: Biomass extraction;

Biorenew_P: Biomass production and renewable; Biomass_X: Biomass exports

Figure 4. GGMs (Gaussian Graphical Models) for EU-13, 1995-2016:

a - EBIC and LASSO; b - Partial correlation (source: authors' research)

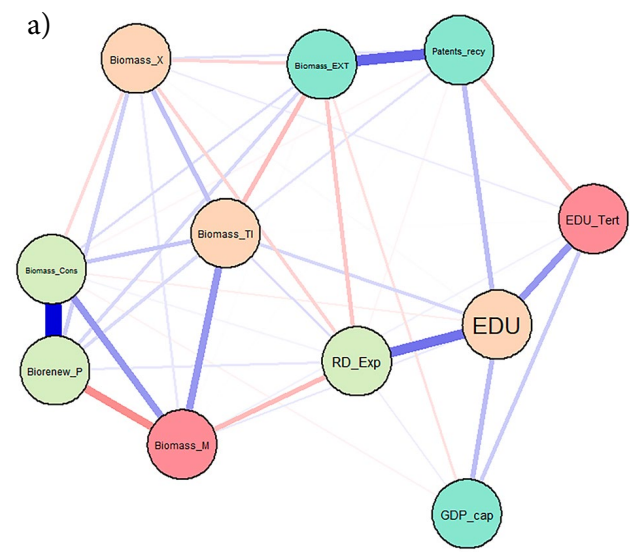

GDP_cap: GDP per capita; RD_Exp: R\&D expenditures; EDU: Educated population; EDU_Tert: Tertiary education; Patents_recy: Patents on recycling and secondary; Biomass_Cons: Biomass consumption;

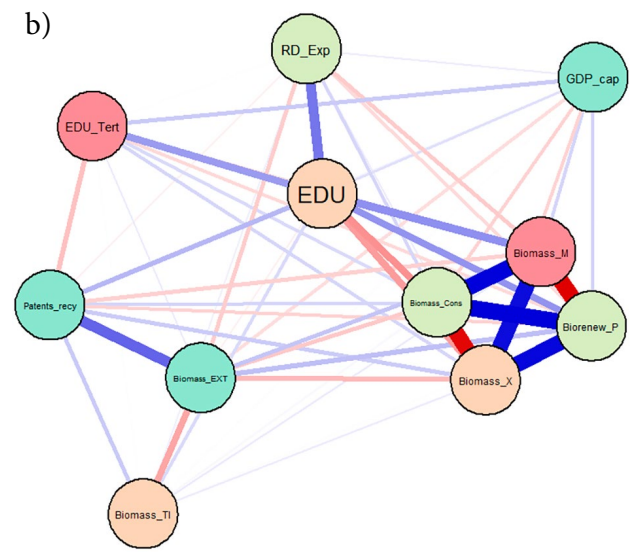

Biomass_TI: Biomass transformation input; Biomass_M: Biomass imports; Biomass_EXT: Biomass extraction;

Biorenew_P: Biomass production and renewable; Biomass_X: Biomass exports

Figure 5. GGMs (Gaussian Graphical Models) for EU-15, 1995-2016: a - EBIC and LASSO; b - Partial correlation (source: authors' research) 
On the other hand, when we have processed the two GGMs on the EU-15 panel (Figure 5), we have noticed that the interlinkages tend to dissipate in intensity, in a much structured order that leads to the final output on GDP per capita.

In case of EU-15 MS, all the education and innovation coordinates (EDU, EDU_Tert, Patents_recy) are found at the core of GDP per capita and bioeconomy proceedings, while the research and development activities and associated financial efforts $\left(R D \_E x p\right)$ are directed mainly towards biomass processes (a convex polygon on consumption, production, exports and imports, along with extraction and transformation input), with important spillovers effects on economic development.

Hence, based on GGM results, the 2nd hypothesis, H2: There are tight overall linkages between the bioeconomy credentials significantly shaped by the intellectual capital factors and economic development, is fulfilled (more emphasized for the EU-13).

\section{Conclusions}

In our study we have performed an advanced analysis regarding the determinants and implications of bioeconomy and intellectual capital on economic development, distinctively for the new EU-13 MS (mainly, CEE countries) and the old EU-15 MS. The research was configured on the primordial significance of bioeconomy in the new millennium, jointly with intellectual capital factors, as main drivers for knowledge on RD\&I support, and highly-skilled people into the biotechnology domain.

Our research endeavour aimed to evaluate several modellers of bioeconomy outcomes within the EU under the significant impact of intellectual capital factors and in interdependency with the economic development, by analysing two hypotheses.

Thus, for the $1^{\text {st }}$ hypothesis the results outlined that tertiary education represents a paramount factor that generates welfare by GDP per capita and bioeconomy enhancement both for the EU-13 MS, and EU-15 MS. Beneficial effects on GDP per capita are also registered particularly through the biomass transformation process, and increased resource productivity, in the case of both EU-13 and EU-15, more visible for the old EU MS. On the other hand, the innovation activity positively reverberates only in the case of EU-15.

In order to examine the $2^{\text {nd }}$ hypothesis, when the general SEM model was applied, the results entailed important interlinkages among the intellectual capital, bioeconomy credentials, and their influence upon economic development, both for the new and old EU MS. The comparative analysis of the two panels reveals that, tertiary education generates more beneficial impacts upon bioeconomy outcomes and GDP per capita in the case of the EU-15, while for the EU-13, the effects are adverse. The explanation arises from wide emigration flows of highly skilled persons from the EU-13 countries (developing countries) to EU-15 countries (mostly, developed MS). The number of patents on recycling and secondary raw materials, non-tertiary educational attainment and $R \& D$ expenditures generate positive effects upon bioeconomy outcomes both for the EU-13, and EU-15, more visible for the EU-13. Thus, the need for R\&D expenditures and innovation are essential for the EU-13 MS. As regards 
the bioeconomy implications jointly with intellectual capital factors upon GDP per capita, the biomass transformation process and biomass imports induce beneficial effects both for the EU-13, and EU-15, while biomass extraction and biomass exports lead to decreasing of GDP per capita in both considered panels.

GGMs grasp that intellectual capital and bioeconomy variables predict one-another with strong linkages with GDP per capita and advanced spillovers effects especially in the case of EU-13, thus highlighting important causal relationships between the observed variables used throughout the entire research endeavour. These models reinforce previous results and show that education, innovation and research, along with important bioeconomy credentials, are at the core of economic development of both EU-13 and EU-15.

The obtained results contribute to the field and increase awareness on the keen need to redesign specific strategies/policies for a sustainable bioeconomy, which are foremost within the EU. A targeted policy is to raise the allocation for RD\&I in sectors enclosed by bioeconomy. That is why policymakers have "to know what fields of science are involved in innovation and how they are organised, as this will help to appreciate the strengths and challenges present in this changing context" and to plan educational programmes and of actions to endorse bioeconomy's sectors (Dybdahl \& Iversen, 2019, p. 204). Carrying out the Nordic strategies as good practices actions, such as: "changing mindsets and consumer behaviour" by insuring the base for "reuse, recycling and upcycling of bio-based products, while limiting waste", behaviour which most of the EU-13 MS are not used to, neither the authorities, nor the consumers; education and acquaintances of bioeconomy "sustainable practices, from kindergarten to university" (Nordic Council of Ministers, 2018, p. 29). In this vein, also Pyka and Prettner (2018, p. 337) pointed out that "a bioeconomic innovation will only be successful when consumers accept it". The roles of media, specific programmes for education, RD\&I (such us Horizon 2020) (Leal Filho et al., 2017), reducing food and plastic waste by government educational programs, creating national recycling programs, or providing financial packages to less developed or developing countries to build a waste management infrastructure become fundamental strategies for these countries and some of the requisite actions, especially for EU-13.

The main limitations of our research consist of reduced data availability for some of the EU countries as regards the bioeconomy features. Therefore, our future research will envisage a detailed analysis performed for specific sectors of the bioeconomy across the EU MS, as Dybdahl and Iversen (2019) underlined. The obtained results may contribute to the future research endeavour by including other variables that might also be essential for economic and sustainable development (such as health and well-being dimensions - quality of life) and the role of migrants/different ethnic groups by considering the works of Dinca and Luches (2018) in relation to the intellectual capital.

\section{Acknowledgements}

We would like to thank the reviewers for their accurate and thoughtful comments that were very useful in enhancing the final research. 


\section{Author contributions}

MC and GGN settled the general pattern of the paper. Authors were altogether involved in development of the work, data collection, analysis and interpretation, drafting the article, writing the paper and approved its final version.

\section{Disclosure statement}

The authors declare that they do not have competing financial, professional, or personal interests from other parties.

\section{References}

Adamowicz, M. (2017). Bio-economy as a concept of development strategies in the European Union. Journal of International Business Research and Marketing, 2(4), 7-12.

https://doi.org/10.18775/jibrm.1849-8558.2015.24.3001

Alsaleh, M., Abdul-Rahim, A. S., \& Mohd-Shahwahid, H. O. (2017). Determinants of technical efficiency in the bioenergy industry in the EU28 region. Renewable and Sustainable Energy Reviews, 78, 1331-1349. https://doi.org/10.1016/j.rser.2017.04.049

Anghel, I., Siminică, M., Cristea, M., Noja, G. G., \& Sichigea, M. (2019). Bioeconomy credentials and intellectual capital: a comparative modelling approach for the E.U.-13 and E.U.-15. Economic Research-Ekonomska Istraživanja, 32(1), 2699-2722. https://doi.org/10.1080/1331677X.2019.1653212

Antoneac, R., \& Dobrota, C. E. (2017). Funding studies abroad and in Romania. In Economic and Social Development: Book of Proceedings, Madrid, Spain (pp. 441-451). https://bib.irb.hr/datoteka/894427.Book_of_Proceedings_esdMadrid_2017_Online2.pdf\#page=451

Barcenilla, S., Gimenez, G., \& Lopez-Pueyo, C. (2019). Differences in total factor productivity growth in the European Union: the role of human capital by income level. Prague Economic Papers, 28(1), 70-85. https://doi.org/10.18267/j.pep.689

Baum, F. C. (2006). An introduction to modern econometrics using stata. Stata Press.

Bildirici, M., \& Ozaksoy, F. (2018). An analysis of biomass consumption and economic growth in transition countries. Economic Research-Ekonomska Istraživanja, 31(1), 386-405. https://doi.org/10.1080/1331677X.2018.1427610

BIOEAST. (2018). BIOEAST Vision Paper. BIOEAST-Central and Eastern European Initiative for Knowledge-Based Agriculture, Aquaculture and Forestry in the Bioeconomy. http://www.bioeast. eu/article/bioeastvisionpaper23022018

Birner, R. (2018). Bioeconomy concepts. In I. Lewandowski (Ed.), Bioeconomy: Shaping the transition to a sustainable, biobased economy. Springer. https://doi.org/10.1007/978-3-319-68152-8

Bracco, S., Calicioglu, O., Gomez San Juan, M., \& Flammini, A. (2018). Assessing the contribution of bioeconomy to the total economy: a review of national frameworks. Sustainability, 10(6), 1698. https://doi.org/10.3390/su10061698

Cîrstea, Ș. D., Cîrstea, A., Popa, I. E., \& Radu, G. (2019). The role of bioenergy in transition to a sustainable bioeconomy - Study on EU countries. Amfiteatru Economic, 21(50), 75-89. https://doi.org/10.24818/EA/2019/50/75

Dediu, I. (2014). Bioeconomia - O creatie stiintifica romaneasca. Ecology, 2(33), 59-61 (in Romanian). https://ibn.idsi.md/sites/default/files/imag_file/Bioeconomia\%20o\%20creatie\%20stiintifica\%20 romaneasca.pdf

Dinca, M., \& Luches, D. (2018). Work Integration of the Roma: Between Family and Labor Market. Sustainability, 10(5), 1495. https://doi.org/10.3390/su10051495 
Dobra, A., Eicher, T., \& Lenkoski, A. (2008). Modeling uncertainty in macroeconomic growth determinants using Gaussian Graphical models (Working Paper 87). Center for Statistics and the Social Sciences, University of Washington, Washington, USA. https://doi.org/10.1016/j.stamet.2009.11.003

Dobrzanski, P. (2018). Innovation expenditures efficiency in Central and Eastern European Countries. Zbornik radova Ekonomskog fakulteta u Rijeci: časopis za ekonomsku teoriju i praksu, 36(2), 827-859.

Dragoi, M. C., Andrei, J. V., Mieila, M., Panait, M., Dobrota, C. E., \& Lădaru, R. G. (2018). Food safety and security in Romania - An econometric analysis in the context of national agricultural paradigm transformation. Amfiteatru Economic, 20(47), 134-150. https://doi.org/10.24818/EA/2018/47/134

Dybdahl, L. M., \& Iversen, E. J. (2019). What knowledge does the bioeconomy build upon?. In A. Klitkou, A. M. Fevolden, \& M. Capasso (Eds.), From waste to value. Valorisation pathways for organic waste streams in circular bioeconomies. Routledge. https://doi.org/10.4324/9780429460289

Epskamp, S., Waldorp, L., Mottus, R., \& Borsboom, D. (2018). The Gaussian graphical model in cross-sectional and time-series data. Multivariate Behavioral Research, 53(4), 453-480. https://doi.org/10.1080/00273171.2018.1454823

European Commission. (2010). Europe 2020. A European strategy for smart, sustainable and inclusive growth. $\operatorname{COM}(2010)$ 2020, Brussels, Belgium. https://ec.europa.eu/eu2020/pdf/COMPLET\%20 EN\%20BARROSO\%20\%20\%20007\%20-\%20Europe\%202020\%20-\%20EN\%20version.pdf

European Commission. (2012). Communication from the Commission to the European Parliament, The Council, the European Economic and Social Committee and the Committee of the Regions. Innovating for sustainable growth: A bioeconomy for Europe. Brussels, Belgium. https://ec.europa.eu/research/ bioeconomy/pdf/official-strategy_en.pdf

European Commission. (2018). A sustainable Bioeconomy for Europe: Strengthening the connection between economy, society and the environment, Updated Bioeconomy Strategy. Brussels, Belgium. https://ec.europa.eu/research/bioeconomy/pdf/ec_bioeconomy_strategy_2018.pdf\#view=fit\&pagemode $=$ none.

Eurostat. (2019). Database. https://ec.europa.eu/eurostat/data/database

Georgescu-Roegen, N. (1977). Inequality, limits and growth from a bio-economic viewpoint. Review of Social Economy, 35(3), 361-375. https://doi.org/10.1080/00346767700000041

Gomez San Juan, M., Bogdanski, A., \& Dubois, O. (2019). Towards sustainable bioeconomy - Lessons learned from case studies. FAO.

Kaza, S., Yao, L. C., Bhada-Tata, P., \& Van Woerden, F. (2018). What a waste 2.0: A global snapshot of solid waste management to 2050. Urban Development, Washington DC, World Bank. https://doi.org/10.1596/978-1-4648-1329-0

Kung, C.-C. (2018). A dynamic framework of sustainable development in agriculture and bioenergy. Agricultural Economics - Czech, 64(10), 445-455. https://doi.org/10.17221/281/2017-AGRICECON

Leal Filho, W., Pociovalisteanu, D. M., \& Al-Amin, A. Q. (2017). Sustainable economic development. Springer. https://doi.org/10.1007/978-3-319-45081-0

Lewandowski, I., Gaudet, N., Lask, J., Maier, J., Tchouga, B., \& Vargas-Carpintero, R. (2018). Context. In I. Lewandowski (Ed.), Bioeconomy: Shaping the transition to a sustainable, biobased economy. Springer. https://doi.org/10.1007/978-3-319-68152-8

Marcu, N., Siminica, M., Noja, G. G, Cristea, M., \& Dobrota, C. E. (2018). Migrants' integration on the European labor market: A spatial bootstrap, SEM and network approach. Sustainability, 10(12), 4543. https://doi.org/10.3390/su10124543

Luhova, M. (2015). Selected types of investments enabling development of bioeconomy in the region. Economic and Regional Studies, 8(3), 100-110.

McKenzie, D., \& Sasin, M. J. (2007). Migration, remittances, poverty, and human capital: Conceptual and empirical challenges (Policy Research Working Paper, 4272). World Bank, Washington, DC. https://elibrary.worldbank.org/doi/abs/10.1596/1813-9450-4272 
Nedelea, A. M., Mironiuc, M., Huian, M. C., Birsan, M., \& Bedrule-Grigoruta, M. V. (2018). Modeled interdependencies between intellectual capital, circular economy and economic growth in the context of bioeconomy. Amfiteatru Economic, 20(49), 616-663. https://doi.org/10.24818/EA/2018/49/616

Nordic Council of Ministers. (2018). Nordic bioeconomy programme 15 action points for sustainable change. Copenhagen, Denmark. https://doi.org/10.6027/ANP2018-785

OECD. (2008). Handbook on constructing composite indicators: Methodology and user guide. OECD Publishing. http://www.oecd.org/sdd/42495745.pdf

OECD. (2009). The bioeconomy to 2030: Designing a policy agenda. International Futures Programme. https://doi.org/10.1787/9789264056886-en

OECD. (2018). Meeting policy challenges for a sustainable bioeconomy. OECD Publishing. https://doi.org/10.1787/9789264292345-en

Popescu, G., Andrei, J. V., Nica, E., Mieila, M., \& Panait, M. (2019). Analysis on the impact of investments, energy use and domestic material consumption in changing the Romanian economic paradigm. Technological and Economic Development of Economy, 25(1), 59-81. https://doi.org/10.3846/tede.2019.7454

Pyka, A., \& Prettner, K. (2018). Economic growth, development, and innovation: The transformation towards a knowledge-based bioeconomy. In I. Lewandowski (Ed.), Bioeconomy. Springer. https://doi.org/10.1007/978-3-319-68152-8_11

Refsgaard, K., Teras, J., Kull, M., Oddsson, G., Johannesson, T., \& Kristensen, I. (2018). The rapidly developing Nordic bioeconomy: Excerpt from state of the Nordic Region. Nordic Council of Ministers, Copenhagen, Denmark. https://doi.org/10.6027/e8424b2c-en

Ronzon, T., \& M'Barek, R. (2018). Socioeconomic indicators to monitor the EU's bioeconomy in transition. Sustainability, 10(6), 1745. https://doi.org/10.3390/su10061745

Ronzon, T., Santini, F., \& M'Barek, R. (2015). The bioeconomy in the European Union in numbers. Facts and figures on biomass, turnover and employment. European Commission, Joint Research Centre, Institute for Prospective Technological Studies, Spain. https:/ec.europa.eu/jrc/sites/jrcsh/files/ JRC97789\%20Factsheet_Bioeconomy_final.pdf

Sanders, L. (2007). Models in spatial analysis. ISTE Ltd. https://doi.org/10.1002/9780470612255

Schutte, G. (2018). What kind of innovation policy does the bioeconomy need?. New Biotechnology, 40, 82-86. https://doi.org/10.1016/j.nbt.2017.04.003

Stevanovic, T., Ivanovic-Dukic, M., Radenovic, T., \& Radovic, O. (2018). The impact of national intellectual capital on the economic growth in the South-Eastern European countries. Zbornik radova Ekonomskog fakulteta u Rijeci: časopis za ekonomsku teoriju i praksu, 36(2), 777-800.

Tondl, G., \& Vuksic, G. (2003). What makes regions in Eastern Europe catching up? The role of foreign investment, human resources and geography (ZEI Working Papers B 12-2003). University of Bonn, ZEI - Center for European Integration Studies, Bonn, Germany. https://www.econstor.eu/handle/10419/39510

Zemlickienè, V., \& Turskis, Z. (2020). Evaluation of the expediency of technology commercialization: a case of information technology and biotechnology. Technological and Economic Development of Economy, 26(1), 271-289. https://doi.org/10.3846/tede.2020.11918

Zilberman, D., Gordon, B., Hochman, G., \& Wesseler, J. (2018). Economics of sustainable development and the bioeconomy. Applied Economic Perspectives and Policy, 40(1), 22-37. https://doi.org/10.1093/aepp/ppx051

Vargas-Hernandez, J. G., Pallagst, K., \& Hammer, P. (2018). Bio-economy at the crossroads of sustainable development. In S. Dhiman \& J. Marques (Eds.), Handbook of engaged sustainability. Springer. https://doi.org/10.1007/978-3-319-53121-2_52-1

Wooldridge, J. (2013). Introductory econometrics: A modern approach ( $5^{\text {th }}$ ed.). Cengage Learning. https://economics.ut.ac.ir/documents/3030266/14100645/Jeffrey_M._Wooldridge_Introductory_ Econometrics_A_Modern_Approach_2012.pdf 


\section{APPENDIX}

Table A1. Variables enclosed within the econometric models (source: authors' contribution)

\begin{tabular}{|l|l|l|}
\hline \multicolumn{1}{|c|}{ Acronym } & \multicolumn{1}{|c|}{ Explanation } & \\
\hline GDP_cap & Real Gross Domestic Product per capita & Euro \\
\hline RES_Prod & $\begin{array}{l}\text { The GDP divided by domestic material consumption. } \\
\text { It represents "the annual quantity of raw materials extracted } \\
\text { from the domestic territory of the local economy, plus all } \\
\text { physical imports minus all physical exports" (Eurostat) }\end{array}$ & $\begin{array}{l}\text { Euro per kilogram, } \\
\text { chain linked } \\
\text { volumes 2010 }\end{array}$ \\
\hline Biorenew_P & Primary biomass production and renewable energies & $\begin{array}{l}\text { thousands tonnes of } \\
\text { oil equivalent, TOE }\end{array}$ \\
\hline Biomass_Cons & Gross inland consumption of biomass and renewable wastes & TOE \\
\hline Biomass_TI & Transformation input of biomass and renewable wastes & TOE \\
\hline Biomass_EXT & Biomass domestic extraction & thousand tonnes \\
\hline Biomass_X & Biomass exports & TOE \\
\hline Biomass_M & Biomass imports & TOE \\
\hline EDU_Tert & $\begin{array}{l}\text { Educational attainment for tertiary education (levels 5-8) } \\
\text { \% of the } \\
\text { population aged } \\
30-34\end{array}$ \\
\hline EDU & $\begin{array}{l}\text { Educational attainment for upper secondary and post- } \\
\text { secondary non-tertiary education (levels 3-4) }\end{array}$ & $\begin{array}{l}\text { \% of the population } \\
\text { aged 15-64 years }\end{array}$ \\
\hline RD_Exp & $\begin{array}{l}\text { Expenses in R\&D, in order to increase knowledge and the } \\
\text { use of knowledge for new applications. }\end{array}$ & \% of GDP \\
\hline Patents_recy & $\begin{array}{l}\text { Patents on recycling and secondary raw materials appraise } \\
\text { the number of these patents, according to Cooperative } \\
\text { Patent Classification (CPC) }\end{array}$ & Number \\
\hline
\end{tabular}

Table A2. Descriptive statistics, EU-13 and EU-15, 1995-2016 (source: authors' contribution)

\begin{tabular}{|l|c|c|c|c|c|}
\hline \multicolumn{1}{|c|}{ EU-13 } & $\mathrm{N}$ & mean & sd & $\min$ & $\max$ \\
\hline EDU_Tert & 286 & 25.47098 & 12.22245 & 1.0 & 58.7 \\
\hline EDU & 286 & 71.19301 & 14.96761 & 17.1 & 87.6 \\
\hline RD_Exp & 286 & 0.7973706 & 0.4582706 & 0.024 & 2.604 \\
\hline Patents_recy & 286 & 2.908951 & 5.907834 & 0 & 53.82 \\
\hline Biomass_Cons & 286 & 1385.37 & 1548.067 & 0 & 7996 \\
\hline Biomass_TI & 286 & 207.7213 & 389.8592 & 0 & 2622.7 \\
\hline Biomass_M & 286 & 46.78462 & 115.0598 & 0 & 961.4 \\
\hline Biomass_X & 286 & 99.65699 & 171.6912 & 0 & 1081.7 \\
\hline Biorene_P & 286 & 1440.371 & 1528.004 & 0 & 7853.5 \\
\hline Biomass_EXT & 286 & 30371.64 & 42157.8 & -25734.34 & 188549.2 \\
\hline RES_Prod & 286 & 0.7521073 & 0.3967153 & 0.0425 & 2.2946 \\
\hline GDP_cap & 286 & 14072.3 & 6572.38 & 3781.9 & 32651.9 \\
\hline EU-15 & $\mathrm{N}$ & mean & sd & min & max \\
\hline EDU_Tert & 330 & 32.50485 & 10.86537 & 8.6 & 54.6 \\
\hline
\end{tabular}


End of Table A2

\begin{tabular}{|l|c|c|c|c|c|}
\hline \multicolumn{1}{|c|}{ EU-13 } & $\mathrm{N}$ & mean & sd & $\min$ & $\max$ \\
\hline EDU & 330 & 63.11136 & 13.89838 & 19.3 & 87.8 \\
\hline RD_Exp & 330 & 1.882173 & 0.8311624 & 0 & 3.914 \\
\hline Patents_recy & 330 & 18.68476 & 31.4278 & 0 & 244.98 \\
\hline Biomass_Cons & 330 & 4870.97 & 4902.468 & 24.6 & 26174.6 \\
\hline Biomass_TI & 330 & 1641.417 & 2011.849 & 0 & 12111.5 \\
\hline Biomass_M & 330 & 380.7085 & 605.9532 & 0 & 3208.9 \\
\hline Biomass_X & 330 & 148.4706 & 310.9196 & 0 & 1717.3 \\
\hline Biorenew_P & 330 & 4617.05 & 4815.643 & 24.6 & 26740.5 \\
\hline Biomass_EXT & 330 & 86166.37 & 86047.05 & 1082.07 & 402159.8 \\
\hline RES_Prod & 330 & 1.89329 & 0.7859285 & 0.7363998 & 4.1973 \\
\hline GDP_cap & 330 & 43504.74 & 17331.17 & 18643.6 & 110001 \\
\hline
\end{tabular}

Table A3. Unit-root tests, EU-13 and EU-15, 1995-2016 (source: authors' contribution)

\begin{tabular}{|c|c|c|}
\hline EU-13 & \multicolumn{2}{|c|}{ Resid } \\
\hline \multirow[t]{4}{*}{ LLC (Levin-Lin-Chu) } & $\mathrm{p}$-value & 0.0001 \\
\hline & t-statistic & -3.7367 \\
\hline & \multicolumn{2}{|c|}{ ADF regressions: 1 lag; Time trend included } \\
\hline & \multicolumn{2}{|c|}{ LR variance: Bartlett kernel, 8.00 lags average } \\
\hline \multirow[t]{3}{*}{ Im-Pesaran-Shin } & p-value & 0.0008 \\
\hline & t-statistic & -3.1554 \\
\hline & \multicolumn{2}{|c|}{$\begin{array}{l}\text { ADF regressions: No lags included } \\
\text { AR parameter: Panel-specific; Time trend included }\end{array}$} \\
\hline \multirow[t]{3}{*}{ Harris-Tzavalis } & p-value & 0.1319 \\
\hline & Statistic (rho) & 0.6271 \\
\hline & $\mathrm{Z}$ & -1.1173 \\
\hline \multirow{3}{*}{$\begin{array}{l}\text { Fisher-type } \\
\text { Based on Augmented } \\
\text { Dickey-Fuller (ADF) tests }\end{array}$} & p-value & 0.0002 \\
\hline & Inverse chi-squared (26) & 51.7194 \\
\hline & Modified inv. chi-squared & 3.5667 \\
\hline EU-15 & \multicolumn{2}{|c|}{ Resid } \\
\hline \multirow[t]{4}{*}{ LLC (Levin-Lin-Chu) } & p-value & 0.0000 \\
\hline & t-statistic & -4.6817 \\
\hline & \multicolumn{2}{|c|}{ ADF regressions: 1 lag; Time trend included } \\
\hline & \multicolumn{2}{|c|}{ LR variance: Bartlett kernel, 8.00 lags average } \\
\hline \multirow[t]{3}{*}{ Im-Pesaran-Shin } & p-value & 0.0000 \\
\hline & t-statistic & -4.0149 \\
\hline & \multicolumn{2}{|c|}{$\begin{array}{l}\text { ADF regressions: No lags included } \\
\text { AR parameter: Panel-specific; Time trend included }\end{array}$} \\
\hline
\end{tabular}


End of Table A3

\begin{tabular}{|l|l|c|}
\hline \multirow{3}{*}{ Harris-Tzavalis } & p-value & 0.0913 \\
\cline { 2 - 3 } & Statistic (rho) & 0.6204 \\
\cline { 2 - 3 } & Z & -1.3326 \\
\hline $\begin{array}{l}\text { Fisher-type } \\
\text { Based on Augmented Dickey- } \\
\text { Fuller tests }\end{array}$ & p-value & 0.0001 \\
\cline { 2 - 3 } & Inverse chi-squared (30) & 58.3553 \\
\cline { 2 - 3 } & Modified inv. chi-squared & 3.6607 \\
\hline $\begin{array}{l}\text { Ho: (All) Panels contain unit roots; } \\
\text { Ha: Panels are stationary/ At least one panel is stationary. }\end{array}$ \\
\hline
\end{tabular}

Table A4. SEM results for Cronbach's alpha, EU-13 and EU-15, 1995-2016 (source: authors' contribution)

\begin{tabular}{|l|c|c|c|c|c|c|}
\hline \multirow{2}{*}{} & \multicolumn{5}{|c|}{ Test scale = mean (standardized items), average } \\
\cline { 2 - 7 } & \multicolumn{3}{|c|}{ EU-13 } & \multicolumn{3}{c|}{ EU-15 } \\
\hline Item & Obs & Sign & alpha & Obs & Sign & alpha \\
\hline Biorenew_P & 286 & + & 0.7916 & 330 & + & 0.7770 \\
\hline Biomass_TI & 286 & + & 0.7934 & 330 & + & 0.7767 \\
\hline Biomass_EXT & 286 & + & 0.8081 & 330 & + & 0.8094 \\
\hline Biomass_Cons & 286 & + & 0.7934 & 330 & + & 0.7760 \\
\hline Biomass_M & 286 & + & 0.8040 & 330 & + & 0.8203 \\
\hline Biomass_X & 286 & + & 0.8295 & 330 & + & 0.8133 \\
\hline EDU_Tert & 286 & + & 0.8512 & 330 & + & 0.8406 \\
\hline EDU & 286 & + & 0.8286 & 330 & + & 0.8161 \\
\hline Patents_recy & 286 & + & 0.8138 & 330 & + & 0.8110 \\
\hline RD_Exp & 286 & + & 0.8513 & 330 & + & 0.8158 \\
\hline GDP_cap & 286 & - & 0.8590 & 330 & + & 0.8575 \\
\hline Totalscale & & & 0.8359 & & & 0.8265 \\
\hline
\end{tabular}

Table A5. SEM results for Wald tests, EU-13 and EU-15, 1995-2016 (source: authors' contribution)

\begin{tabular}{|l|c|c|c|c|c|c|}
\hline \multirow{2}{*}{\multicolumn{1}{|c}{ Variables }} & Chi2 & df & p-value & Chi2 & df & p-value \\
\cline { 2 - 7 } & \multicolumn{5}{|c|}{ EU-13 } & \multicolumn{4}{c|}{ EU-15 } \\
\hline Biorenew_P & 289.26 & 2 & 0.0000 & 136.23 & 2 & 0.0000 \\
\hline Biomass_TI & 314.59 & 2 & 0.0000 & 121.91 & 2 & 0.0000 \\
\hline Biomass_EXT & 345.36 & 2 & 0.0000 & 319.79 & 2 & 0.0000 \\
\hline GDP_cap & 84.39 & 6 & 0.0000 & 82.17 & 6 & 0.0000 \\
\hline Biomass_Cons & 21.73 & 2 & 0.0000 & 92.84 & 2 & 0.0000 \\
\hline Biomass_M & 27.09 & 2 & 0.0000 & 18.84 & 2 & 0.0001 \\
\hline Biomass_X & 47.67 & 2 & 0.0000 & 22.96 & 2 & 0.0000 \\
\hline
\end{tabular}

H0: all coefficients excluding the intercepts are 0 ;

We can thus reject that null hypothesis for each equation. 
Table A6. SEM results for Goodness-of-fit tests, EU-13 and EU-15, 1995-2016 (source: authors' contribution)

\begin{tabular}{|c|c|c|}
\hline \multicolumn{3}{|r|}{ EU-13 } \\
\hline Fit statistic & Value & Description \\
\hline $\begin{array}{l}\text { Likelihood ratio } \\
\text { chi2_ms }(26) \\
p>\text { chi2 } \\
\text { chi2_bs }(38) \\
\text { p > chi2 }\end{array}$ & $\begin{array}{l}3644.448 \\
0.000 \\
4447.843 \\
0.000\end{array}$ & $\begin{array}{l}\text { model vs. saturated } \\
\text { baseline vs. saturated }\end{array}$ \\
\hline $\begin{array}{l}\text { Information criteria } \\
\text { AIC } \\
\text { BIC }\end{array}$ & $\begin{array}{l}2434.602 \\
2551.594\end{array}$ & $\begin{array}{l}\text { Akaike's information criterion } \\
\text { Bayesian information criterion }\end{array}$ \\
\hline $\begin{array}{l}\text { Baseline comparison } \\
\text { CFI } \\
\text { TLI }\end{array}$ & $\begin{array}{l}0.179 \\
-0.298\end{array}$ & $\begin{array}{l}\text { Comparative fit index } \\
\text { Tucker-Lewis index }\end{array}$ \\
\hline $\begin{array}{l}\text { Size of residuals } \\
\text { SRMR } \\
\text { CD }\end{array}$ & $\begin{array}{l}0.280 \\
0.842\end{array}$ & $\begin{array}{l}\text { Standardized root mean squared residual } \\
\text { Coefficient of determination }\end{array}$ \\
\hline \multicolumn{3}{|r|}{ EU-15 } \\
\hline \multicolumn{3}{|c|}{ Fit statistic Value Description } \\
\hline $\begin{array}{r}\text { Likelihood ratio (LR) } \\
\text { chi2_ms }(26) \\
p>\text { chi2 } \\
\text { chi2_bs }(38) \\
p>\text { chi2 }\end{array}$ & $\begin{array}{l}3649.709 \\
0.000 \\
4286.799 \\
0.000\end{array}$ & $\begin{array}{l}\text { model vs. saturated } \\
\text { baseline vs. saturated }\end{array}$ \\
\hline $\begin{array}{l}\text { Information criteria } \\
\text { AIC } \\
\text { BIC }\end{array}$ & $\begin{array}{l}9395.759 \\
9517.330\end{array}$ & $\begin{array}{l}\text { Akaike's information criterion } \\
\text { Bayesian information criterion }\end{array}$ \\
\hline $\begin{array}{l}\text { Baseline comparison } \\
\text { CFI } \\
\text { TLI }\end{array}$ & $\begin{array}{l}0.146 \\
-0.350\end{array}$ & $\begin{array}{l}\text { Comparative fit index } \\
\text { Tucker-Lewis index }\end{array}$ \\
\hline $\begin{array}{l}\text { Size of residuals } \\
\text { SRMR } \\
\text { CD }\end{array}$ & $\begin{array}{l}0.554 \\
0.756\end{array}$ & $\begin{array}{l}\text { Standardized root mean squared residual } \\
\text { Coefficient of determination }\end{array}$ \\
\hline
\end{tabular}

